\title{
De stand van het sociale domein: een perpetuum mobile
}

\author{
Paul L. Kocken · Mirjam M. Y. de Klerk · Matthea van Leeuwen · A. J. J. (Toon) Voorham
}

(C) Bohn Stafleu van Loghum is een imprint van Springer Media B.V., onderdeel van Springer Nature 2018

De zorg- en dienstverlening in het sociale domein is volop in beweging. We zijn alweer ruim drie jaar op weg na de decentralisatie van drie belangrijke wetten, de Jeugdwet, de Wet maatschappelijke ondersteuning 2015 (Wmo 2015) en de Participatiewet. Het doel van deze wetten is het bevorderen van participatie van burgers in de samenleving. Bij de decentralisaties bestonden bij aanvang bedenkingen, die te maken hadden met de vraag of gemeenten deze omslag op zo'n korte termijn aankonden en of er voldoende financiële middelen beschikbaar waren. Voor een transformatie van de zorg- en dienstverlening in de welzijnssector bestond echter een breed draagvlak. Burgers zouden meer moeten vertrouwen op hun eigen vermogen en de mogelijkheden van steun uit de sociale omgeving. Professionele hulp wordt ingeschakeld als deze bronnen van zelf- en mantelzorg tekortschieten. We zetten in dit themanummer de veranderingen in de zorg in het kader van de Wmo 2015 en de Jeugdwet centraal, en leggen een relatie met aanpalende sectoren die werken onder de Wet publieke gezondheid en de Participatiewet.

Het Sociaal en Cultureel Planbureau constateerde in 2015 dat gemeenten in de eerste jaren vooral bezig waren om de continuïteit van zorg en ondersteuning te waarborgen: de transitie [1]. Intussen zijn we een aantal jaar verder en is het de vraag of gemeenten

dr. P. L. Kocken $(\triangle)$

TNO, Leiden, Nederland

paul.kocken@tno.nl

dr. M. M. Y. de Klerk

SCP, Den Haag, Nederland

M. van Leeuwen

ZonMw, Den Haag, Nederland

dr. A. J. J. Voorham

Rotterdam, Nederland de stap naar de transformatie van het sociale domein hebben gezet. Het gaat dan om echte vernieuwing van de zorg, dus bijvoorbeeld een meer integrale wijze van werken, het bieden van maatwerk, het inzetten van het eigen netwerk, meer preventieve activiteiten en meer sturen op effectieve en efficiënte oplossingen. Ook kan de vraag worden gesteld of burgers inmiddels profiteren van de verwachte positieve werking van die transformatie van de zorg.

In dit themanummer vindt $\mathrm{u}$ oorspronkelijke bijdragen van wetenschappelijk evaluatieonderzoek naar de Wmo 2015 en de Jeugdwet, inclusief een artikel over initiatieven in het land waarin een verbinding wordt gelegd tussen de welzijns- en gezondheidszorg in het jeugddomein. Het blijkt dat de transformatie nog lang zover niet is. De evaluatie van de Wmo concludeert dat de gewenste cultuur- en gedragsverandering bij partijen die de Wmo 2015 uitvoeren nog meer tijd vergt. Het ministerie van Volksgezondheid, Welzijn en Sport gaat in programma's zoals Langer Thuis door op de ingeslagen weg. Het zet in op manieren om samenhang in de zorg en ondersteuning te creëren, en de samenhang binnen regio's te verbeteren. Ook de evaluatie van de Jeugdwet concludeert dat de doelen nog onvoldoende zijn gehaald. De verantwoordelijke minister voor de uitvoering van de Jeugdwet heeft een actieprogramma Zorg voor Jeugd in het leven geroepen, dat de transformatie moet versnellen. De veranderopgave in de jeugdsector is na de invoering van de Jeugdwet nog onverminderd groot [2]. Gesteld wordt dat het jeugdstelsel de domeinen onderwijs, veiligheid en huisvesting onvoldoende integraal bij de transformatie betrekt. Het actieprogramma moet onder meer stimuleren dat meer kinderen thuis kunnen opgroeien en dat de toegang tot hulp wordt verbeterd. Dit betekent dat, net als bij de professionals die de Wmo 2015 uitvoeren, moet worden geïnvesteerd in het vakmanschap van de jeugdprofessionals. 
In de Spectrum-bijdragen wordt vanuit verschillende gezichtspunten een kritische beschouwing gegeven over cliëntbetrokkenheid bij de zorg in het sociale domein. Ook hier wordt duidelijk dat nog veel voor verbetering vatbaar is. Interessant is bijvoorbeeld om opinies te lezen waarin gesteld wordt dat gemeenten onvoldoende oog hebben voor mantelzorgers en voor het betrekken van jongeren bij het beleid. De rubrieken Forum en Praktijk staan bol van voorbeelden van innovatieve lokale projecten en uitvoeringspraktijken die een integrale benadering in de zorg voorstaan. Boeiend is dat in het hele land wordt geëxperimenteerd met cliëntbetrokkenheid, vraaggestuurde zorg, bekostigingsmodellen, aanbesteding en managementmodellen in het sociale domein. Dit bevestigt het beeld dat de lokale zorg enorm in beweging is.

Op weg naar een betere hulp- en dienstverlening in het sociale domein leren we van vallen en opstaan. We vragen ons echter wel af of niet nog meer stelselmatig onderzoek moet worden gedaan naar de vernieuwingen en er nieuwe manieren moeten worden gezocht om van elkaar te leren. Welke lokaal 'uitgevonden' modellen zijn de moeite waard om te verspreiden naar andere delen van het land? De artikelen over de projectenparade en kennisinfrastructuur gaan op deze verspreidingsvraag in. Vanwege het belang van het leren van elkaar in het sociale domein en de brede doelgroep waarvoor deze artikelen interessant zijn, is dit themanummer dankzij ZonMw in zijn geheel vrij toegankelijk gemaakt. Hiermee hopen we te stimuleren dat beschouwingen en mooie voorbeelden daadwerkelijk zullen worden verspreid en benut om de transformatie verder vorm te geven.

Het sociale domein is een perpetuum mobile zoals Escher hem graag tekende, maar ook weer niet. De zorg- en dienstverlening is in beweging gezet en moet uit zichzelf blijven bewegen. Zijn we ooit klaar? Wij denken van niet. Gaat de transformatie slagen? Dat hangt ervan af. De energie die daarvoor nodig is zal niet vanzelf ontstaan. Nodig zijn zelfsturende burgers, vakkundige professionals, helpende budgetten, slimme kennisinfrastructuren en evidence uit onderzoek. Dit themanummer betreft een momentopname van de veranderingen in het sociale domein. We hopen hiermee mensen te inspireren om de zorg in beweging te houden, zodat de burger erop vooruitgaat.

\section{Literatuur}

1. Pommer E, Boelhouwer J, redactie. Overall rapportage sociaal domein 2015. Rondom de Transitie. Den Haag: Sociaal en Cultureel Planbureau; 2016.

2. Transitie Autoriteit Jeugd. Tussen droom en daad. Op weg naar een volwassen jeugdstelsel. Vierde Jaarrapportage. Den Haag: TransitieAutoriteit Jeugd; 2018. 